form ${ }_{A \wedge A D E A M L S B}$

Vol I4, No 4 (202I) https://doi.org/10.7577/formakademisk.4655

\author{
Úrsula Bravo \\ Assistant Professor \\ Universidad del Desarrollo, Chile \\ ubravo@udd.cl
}

Erik Bohemia

Associate Professor (PhD)

Oslo Metropolitan University, Norway erikbohe@oslomet.no

\title{
Design Process Models as Metaphors in Education Context ${ }^{1}$
}

\begin{abstract}
We argue that visual representations of design processes contribute toward social and material practices of design(ing). They are used as didactic devices. We will discuss them using metaphors to illustrate that they are active material devices of which circulation, production and consumption are informed and informing perceived complexities, ambiguities and paradoxes associated with design. We propose a follow-up study to investigate how teachers and designers use and interpret visual design process models. The reason is to identify how these models are informing what design is as we are interested to understand how these models are contributing to the development of Design Literacies.
\end{abstract}

Keywords:

visual representations, design education, didactic image, design thinking models.

\section{INTRODUCTION}

More than three decades ago Gather Morgan (1997 [1986]) published a book entitled "Images of Organization". In his book Morgan explored organisations through lenses of eight metaphors: (i) organizations as machines, (ii) living organisms, (iii) brains, cultures, (iv) political systems, (v) psychic prisons, (vi) flux, (vii) transformation, and (viii) instruments of domination. Wilkes (1989, p. 67), suggested "that metaphor is an especially appropriate tool for assisting us to appreciate, interpret and understand" complexities, ambiguities and paradoxes associated with organisations. Metaphors contribute towards production of organisational cultures and how we can think of organisations, including their possibilities and limitations (Jermier \& Forbes, 2011). We would like to extend this idea to design process models.

The motivation to study the design process models is that they 'represent' how design practices are conceived (Wynn \& Clarkson, 2005). Chaplin (1994, cited by Banks, 2007, p. 17) suggested that "representation has the following three properties:

1. its form is not dictated solely or even at all by the thing represented but by set of convention codes 
2. [...] but only [comprehensible] to viewers who understand the convention

3. reflects and constitutes social process

4. the representation has some kind of intentional force behind it (agency)

Representations, including representations of design process models, embody sets of shared values, cultural codes, concepts and "emotions we associate with them" (Hall, 1997, p. xix). According to Hall (1997, p. xvii) "representation is one of the central practices that produces culture", including professsional cultures such as that of design. Holliday (1999) refers to these professional cultures as 'small cultures'.

Hall (1997) suggests that "in part, we give things meaning by how we represent them - the words we use about them, the stories we tell about them, the images of them we produce, the emotions we associate with them, the way we classify and conceptualize them, the values we place on them" ( $p$. xix, our emphases). In this sense the designing is the 'thing' to which a meaning is given by representation through the design process models.

The representations do not have any meaning in themselves, "it is we who fix meaning" (Hall, 1997, p. 7). Therefore, in order to 'translate' and to "read visual images", such as the design process models, the members of the cultural group (e.g. designers) "must share, broadly speaking, the same cultural codes" ( $p . x)$, as it is "only viewers who understand the conventions can read these" visual representations (Banks, 2007, p. 1). For example, the visualisation of a time has developed its conventions. The past time might be related to what was 'left behind' and the future time to what 'comes forward'. One can visualise this as if a person is standing with their back turned on the past and facing the future (Meirelles, 2013). In graphic terms, this translates into horizontal lines that can be 'read' from left to right, where the left end represents the 'beginning' and the right represents the 'end'. Thus, in this way of representing a time direction, a situation that happened in the past must be placed to the left of another element that occurred afterwards. However, Kress and van Leeuwen (2006) suggested that direction of reading, including a time, cannot be assumed. For example, Tversky (2001) suggested that those writing/reading right to left also tended to map temporal concepts from right to left. Mijksenaar (1974, p. 19) illustrated how African miners read instructions of a cartoon, which was designed to be read from left to right, from right to left and thus reversing the proposed set of actions. The outcome was that rather than loading stones the miners were off loading them.

The design process models stand for or represent concepts and ideas about design. The representations are constructed by those producing (inscribing) as well by those using (consuming) and interpreting these models (Bowker \& Star, 2000) $)^{2} .1$ The circulation, production and consumption of these visual design process models are constituting and sustaining the 'cultures of designing'. They act as a focal point to initiate the 'uninitiated', the novices, such as students (Bobbe, Krzywinski, \& Woelfel, 2016; Howard, Culley, \& Dekoninck, 2008), about what design and designing is (the act of designers). According to Dubberly (2005) "models of design process were developed to help [...] students to learn to design" (p. 29).

Thus, the design process models act as didactic materials, whether it be in classrooms or in offices. According to Díaz Barriga Arceo and Rojas (2002) the use of images, such as the illustrations, concept maps and diagrams, facilitate the processing of information by improving the codification and organisation of information. Therefore, if we understand the design process models as didactic materials then we can reason that they contribute to the development of 'Design Literacies' (e.g. Kolko, 2018; Pacione, 2010).

The Design Literacies can be understood as a set of craft skills such as ability to draw or making a mock-up or producing a prototype (Heller, 2004). However, as design has been increasingly promoted as a creative problem thinking / working / solving activity, we would like to adopt a broader perspective of Design Literacies which can be associated with, for example, creative problem-solving process (Cross, 1982) which in turn has been promoted under the banner of 'Design Thinking' (e.g. Brown, 2009; Buchanan, 1992; Norman \& Verganti, 2013; Pacione, 2017). This way of understanding design(ing) enables it to be increasingly promoted and appropriated well beyond the design disciplines (Glen, Suciu, Baughn, \& Anson, 2015; Razzouk \& Shute, 2012; Riverdale Country School \& IDEO, 2012; Stigliani, 2017) as a method of creative problem solving for professionals of other disciplines under the term of 'Design 
Thinking' (Liedtka \& Ogilvie, 2011; Martin, 2009). Dorst (2011) identified 'Design Thinking' as a new paradigm for dealing with problems in many professions such as Information Technology and Business. It has been suggested that the 'Design Thinking' encourages creative thinking through supporting identification of problems and development of more diverse and user centred solutions (Dorst, 2011; Hassi \& Laakso, 2011; Johansson-Sköldberg, Woodilla, \& Çetinkaya, 2013). We would like further to extend the application of Design Literacies beyond 'production' to encompass practices of consumption of goods and services (Ingram, Shove, \& Watson, 2007) and development of citizenship (Nielsen, 2013).

\section{VISUAL REPRESENTATIONS OF DESIGN PROCESSES}

Many authors have tried to visually represent the design process ${ }^{3}$. The visual design processes models arerecurrent representation of proposed 'fundamental' elements such as steps and types of thinking and feedback loops that take place during the design process (see Table 1). However, each emphasises different aspect and incorporates elements of their own professional or academic context. Given the diversity of authors, their careers and disciplinary linkages, the representations of design process models are diverse, both in their structures such as number of different activities, steps and phases as well as the naming of these. For example, Wölfel, Debitz, Krzywinski, and Stelzer (2012) interviewed 50 designers (15 Industrial and 35 Engineering Designers) who together provided 701 named methods! ( $p$. 1400) The large number which was collected represents 14 different named methods per each of the interviewed person.

These visual representations can range from very precise tasks, starting and ending with defined tasks, with phases which bring together various activities which may overlap with each other. The type of activities involved, also vary including practical procedures (e.g. prototype and test), cognitive skills (e.g. analyse, synthesize) and attitudes required (e.g. empathy). The elements involved, are so many and so varied, that it is impossible to reunite them all in a single diagram. For example, the consider complexity associated with transition between the 'problem' and the 'solution': the process moves from a 'current' to a 'future' situation, from 'analytical thinking' to 'creative synthesis', from 'divergence' to 'convergence', from 'knowing' to 'making', from a 'concrete situation' to the 'abstraction of the ideas and concepts', to finally return to the 'concrete' through the implementation of a proposal. The overwhelming diversity has been noted by scholars trying to examine design process models (Bobbe et al., 2016; Gericke \& Blessing, 2012; Wynn \& Clarkson, 2005).

Dubberly (2005), who collected over 100 design process models, suggests that just recording a design process does not necessarily represent what took place and why. He provides an analogy of recoding the design process to that of recording a photograph. It is "the author [who] chooses where to point the camera-where to begin mapping the process, where to end, and what to put in, what to leave out, how much detail to include" (p. 13). He argues, that "one risk in using this framework is that it neatens a messy world. It may promote an illusion of linearity and mechanism of case and effect" ( $p$. 12). Howard et al. $(2008$, p. 168) research suggests that the design processes are more erratic than most design process model representations suggest.

Similarly, in the field of school education, there are also many variations of the design processes, such as: the diagrams by the Design Thinking for Educators (Riverdale Country School \& IDEO, 2012), Design for Change (Allende, 2016; DFC Global Inc., 2019), and Index (INDEX: Design to Improve Life, 2019; Stenlev \& Boegeskov, 2016). Specific questions we might ask are: What are the characteristics of these visual representations? What elements of the design process are maintained across the models and which are different? What elements inherent to the field of education are incorporated into these design models?

Díaz Barriga Arceo and Rojas (2002) identified five types of illustrations, according to their main function in the teaching-learning process: descriptive, expressive, constructional, functional and algorithmic. These categories are not exclusive of each other rather they are part of a continuum:

1. The descriptive images show what an object is like and what are its most relevant physical characteristics, for example atlases of the human body or the double helix of DNA. 
2. The expressive images seek to generate an emotional impact that mobilizes an attitude toward some phenomenon. For example, a photograph of sea turtles trapped by plastic bags, to promote the non-use of plastic.

3. The constructional images are used to explain the components or elements of an object or system, emphasizing the structural aspects.

4. Functional images show processes and interrelationships that occur between the elements that make up a system, for example the illustration of the water cycle, the food chain or the communication scheme

5. Algorithmic images allow to describe procedures, visualizing possible actions, routes or steps of an activity. They are used to teach procedures to solve problems, for example flow charts.

Most of the design process representations would fall into the algorithmic category, as generally they define steps to solve problems. Some however include functional elements, which try to characterize thought forms (divergent thinking/convergent thinking), axes or dimensions involved in the process design (understanding - doing, concrete, abstract).

Cross (1999/2005), Lawson (2004), Wynn and Clarkson (2005), Dubberly (2005) and others have made a useful contribution in keeping record and analysing different models. For example, Dubberly (2005) classified over 100 models according to their formal characteristics - linear (Figure 1) or cyclical (Figure 2) - or by the context from which they are elaborated: academia, professional consulting, software development.

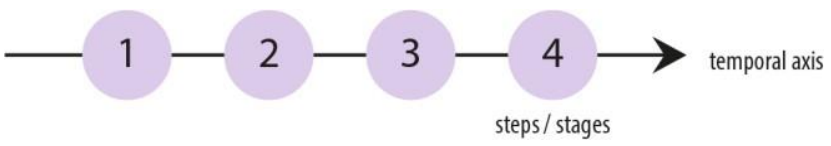

FIGURE 1. A linear Design Process with Specific Steps

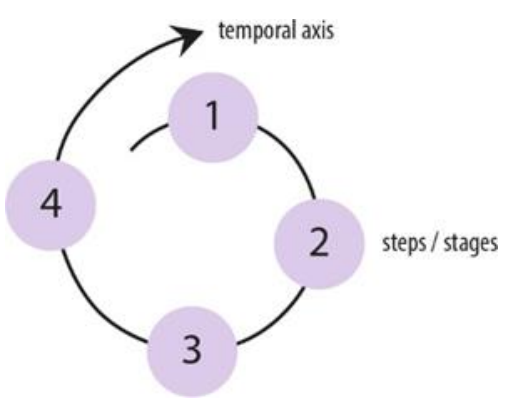

FIGURE 2. A Cyclical Design Process with Specific Steps.

Our interest is to view these design process models using metaphors. During our research we have identifiedthe following metaphors which might be useful for exploring design process models:

- Design Process as Problem Eradication

- Design Process as a Rational Order (e.g. Simon, 1988)

- Design Process as a 'Thinking Journey' (e.g. Alexander, 1964/1973)

- Design Process as a Co-Evolution (Maher, Poon, \& Boulanger, 1996)

- Design Process as an 'Mental State'

- Design processes as a Learning 


\section{DESIGN PROCESS AS A PROBLEM ERADICATION}

Generally, a design process starts with a problem and ends in a solution (see Figure 3 ). But this is a fairly schematic way to define it because a design process can also be activated with the detection of a need or anopportunity (Ulrich \& Eppinger, 2000). If the design process starts with a 'problem' then it is referring to a 'problematization' of an aspect of reality, and the interpretation of the reality is that there is a 'fault' or a deficiency.

a)

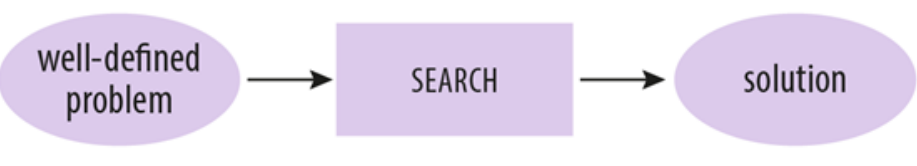

b)

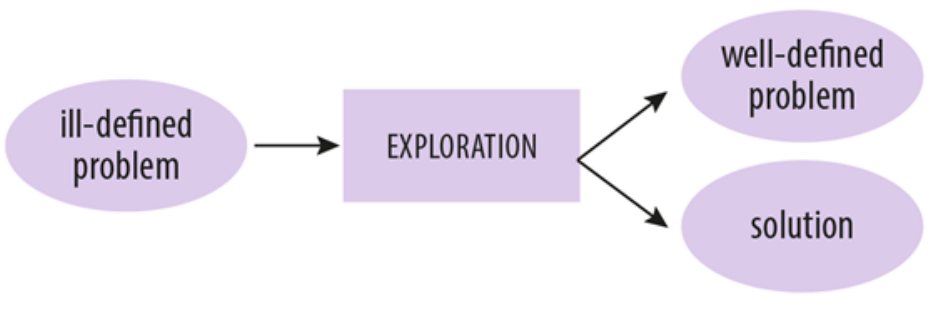

FIGURE 3. A Design Process Models with a 'well-defined' (a) and 'ill-defined' problem (b). Source: Maher et al. (1996, p. 4).

However, Dorst and Cross (2001) suggested that designers do not consider the problem as an objective element-on the contrary-they interpret and construct it from their own contexts, experiences, capabilities and resources, manipulating it during almost the whole process. Implication is, that in this context the problemis never fixed but rather it is continuously 're-moulded' throughout the whole design process. Prior to Dorst's and Cross' article, Rittel and Webber (1973) outlined that "every textbook of systems engineering starts with an enumeration of these phases: 'understand the problems or the mission,' 'gather information,' 'analyse information,' 'synthesize information and wait for the creative leap,' 'work out solution,' or the like. For wicked problems, however, this type of scheme does not work. One cannot understand the problem withoutknowing about its context; one cannot meaningfully search for information without the orientation of a solution concept; one cannot first understand, then solve" (p. 162). However, we would like to consider that this issue is not much related the wicked problems, but rather to a desire to develop a demand. Mol (2008, p. 27) suggested that "advertising agencies are not at all inclined to 'treat demand' as something that is given. For them 'what people want' is not rational phenomenon, they try to create demand. Not with arguments, butthrough seduction" (p. 27). We can extend these very qualities onto designers who with professionals such as advertisers, reporters and journalists, are part of the cultural mediators (du Gay, Hall, Janes, Mackay, \& Negus,1997). It is these professions who are in the business of producing seductive 'meanings' for the consumers to consume (Berger, 2010; Fry, 2011).

\section{DESIGN PROCESS AS A RATIONAL ORDER}

The design process models developed under the influence of engineering, focus on identifying the main stages of the process. They tend to be linear representations, which are organized in a temporal axis (representing a transition of time, from left to right and from top to bottom) - vertical or horizontalon which activities or stages are deployed. Some include tasks, objectives, results and feedback loops. 
'Synthesised' models identify only the main phases. The green rice by Munari (1981/1989) also reflects a linear logic, although clearly the invitation to cook is friendlier and in general well received by design students.

Lawson (2005) stated that these sorts of design process models suggest that transitions will take place during the design process. He used RIBA's sequential design process (see Figure 4 ) to examine how it might be interpreted by a designer. On a practical level, he observed that it might be difficult for a designer to complete phase 1 before the problem is investigated in phase 2 . However, more importantly, relying on his teaching experience, he suggested that students might step over the transition process between phase 1 and phase 2 . Implication of this design process representation is that it might "encourage unproductive procrastination!" (p.34). Further on, in his analyses he outlined that the model does not indicate how the transition (a jump from one of the phases to the next) will take place or how a designer should gather the "information about problem, study it, devise a solution and draw it" (p. 35). In addition, it is not clear how often and what will trigger these jumps.

assimilation general study development communication

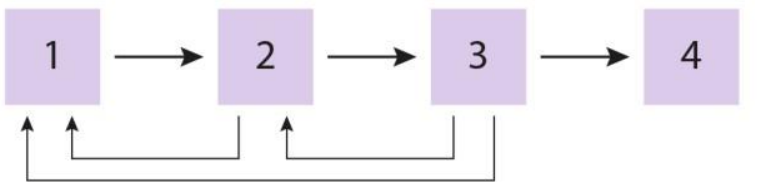

FIGURE 4. A map of design process according to the RIBA plan of worksource: Lawson $(2005$, p. 35)

\section{DESIGN PROCESS AS A CO-EVOLUTION}

Maher et al. (1996) characterised the design process as an exploratory activity, aimed at defining a problem and searching for possible solutions. They suggest that the design process represents into discreet phases "is not good (or correct) description of design" (Maher et al., 1996, p. 3). Unlike the search process, which starts with a well-defined problem (see Figure 3a), exploration begins with an open and poorly defined problem. So, that in addition to generating a solution, a designer must shape and define the problem itself (see Figure $3 b$ ). They suggest that problem and solution are interrelated rather than separate entities. For example, producinga prototype (solution space) might redefine a problem space (Dubberly, 2005), "which in turn will generate a new design space" (solution space) (Maher et al., 1996, p. 4). Thus, the problem space and solution space co- evolve (p. 7), see Figure 5 and Figure 6. To advance their thinking they used analogy of gene mutation.

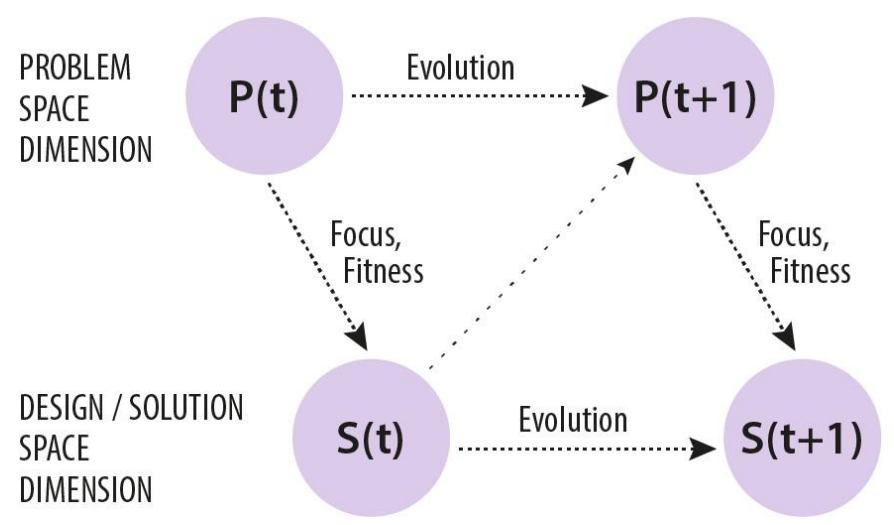

FIGURE 5. Co-evolution of a problem and a solution (based on the genetic mutation metaphor). Source: Maher et al. (1996, p. 7). 
The understanding of the problem and the solution affect each other (Rittel \& Webber, 1973). The informationneeded to understand the problem, depends on the idea that a person has to resolve it and the characteristicsand constraints of a possible solution affect and contribute to redefine the problem. The issue is even more complicated, as according to Cross (2011) designers do not interpret the design brief as a specification for a solution, but as a starting point to explore and to define the problem. Thus, the problem definition is one of the results of the design process.

a)

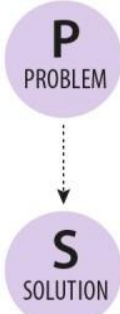

b)

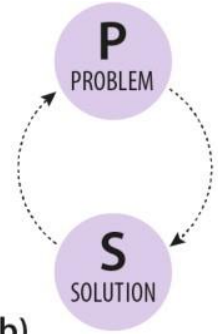

FIGURE 6. From linear positivism (a), to constructivism (b), to phenomenological (c) design process conception.

\section{DESIGN PROCESS AS A 'THINKING JOURNEY'}

The diagrams of Alexander (1964/1973), Dubberly, Evenson, and Robinson (2008) and Kumar (2012), emphasize ways of thinking. Alexander (1964/1973) distinguishes the context of the form and explains that the complexity of the process is due to the successive mental and formal interpretations that the designer makes of the context and the form, see Figure 7. Kumar (2012) establishes two axis that intersect forming fourquadrants. The vertical axis goes from the 'real' to the 'abstract' and the horizontal, from 'knowing' to 'doing'. Each quadrant is associated with a type of thinking (analysis and synthesis) or procedure (research and realization), see Figure 8.

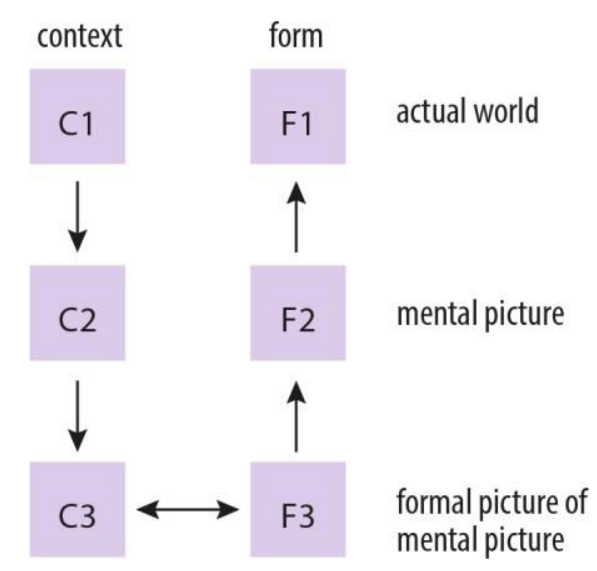

FIGURE 7. Mediated Design Process model source: Alexander (1964/1973, p. 76).

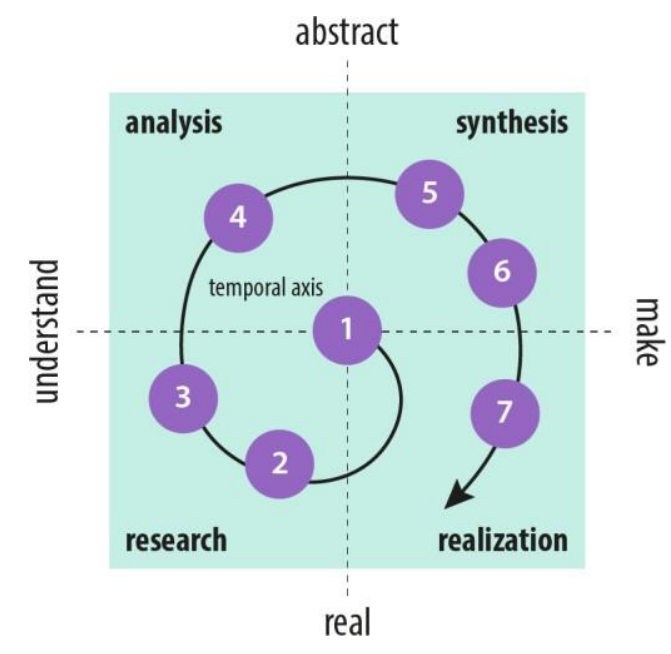

FIGURE 8. A Model of the Design Innovation Process source: Kumar $(2012$, p. 8),

The Double Diamond Model (see Figure 9) proposed by the Design Council (Design Council et al., 2015); which resembles Banathy (1996) 'Dynamics of Divergence and Convergence' model, see Figure 10 (Dubberly, 2005, p. 24); combines a temporal linear structure, with the representation of two main cycles of divergent and convergent thinking, culminating respectively with the definition of the problem and the solution. This model is based on the mnemonic ${ }^{4}$ resource of the 4D: Discover, Define, Develop, 
Deliver (Figure 9) (Dubberly, 2005, p. 6). Both models incorporate two key phases which are made of two steps. The diagrams suggest that as the design progresses during the first step problem finding grows exponentially (discovery/divergence). Then, during the subsequent step (define/convergence) the designs are reduced into a 'single problem'. This is then followed with developing many divergent solutions to address the identified problem in the previous step. Once again, the next step (delivery/ convergence) is to reduce these divergent solutions into a 'single solution'.

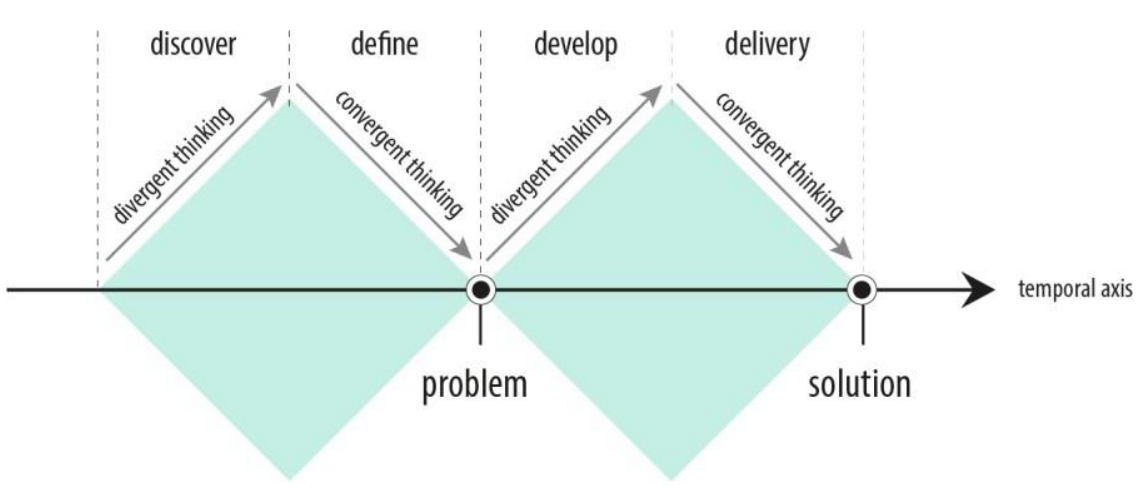

FIGURE 9. Double Diamond model source: Design Council et al. (2015).

The key difference between the Design Council's and Banathy (1996) 'Dynamics of Divergence and Convergence' models is that Banathy (1996) attributes the divergent to involvement of members from different disciplinary backgrounds and it is these disciplinary differences which enable to generate the divergence in thinking. What is not clear, is how the use of same elements which facilitate generating thedivergence in the prior step will also achieve the convergence.

McComb, Cagan, and Kotovsky $(2014,2015)$ suggested that as expert designers select a 'good' direction forsolution quickly they will generate low levels of divergence, which means that they will consider fewer solutions in comparison to novice designers. The implication is that convergence takes place much earlier inthe process then the model might indicate.

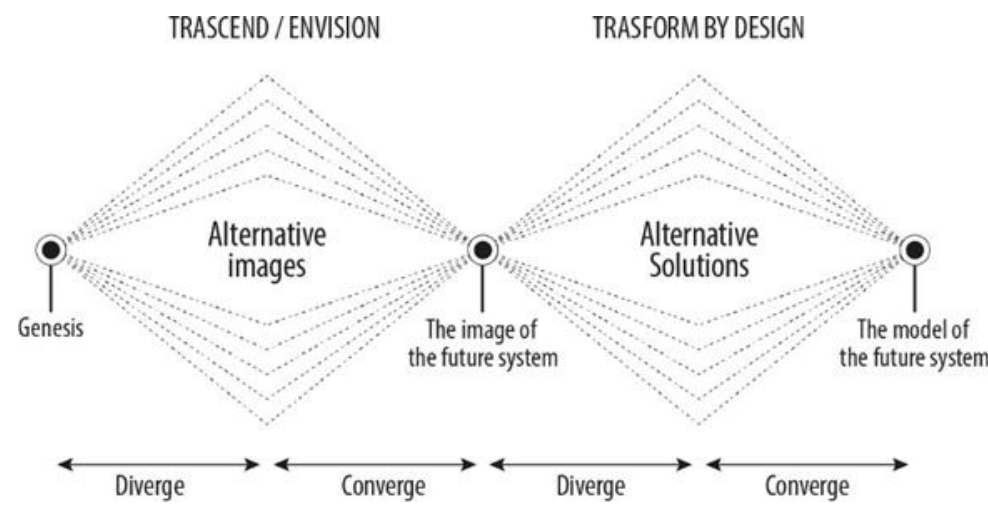

FIGURE 10. Dynamics of Divergence and Convergencesource: Banathy (1996).

The separation of analysis and synthesis can be observed in many design process models (e.g. Double Diamond, see Figure 9). The influence comes from understanding cognitive thinking skills having analysis (divergence) and synthesis (convergence) as separate thinking activities, see Figure 11, even though research suggests otherwise. For example, Koberg and Bagnall (1972/1981) suggested that both analysis 
and synthesiscontinue through a project. This is supported by Eastman (1970, cited by Lawson, 2004) and Akin (1986) that analysis (understanding the problem) is much more integrated with synthesis (generating a solution). For example, Akin (1986) concluded that designers were constantly generating new goals and redefining constraints. Thus, Akin (1986) suggested that analysis is part of all phases of design and synthesis is found veryearly in the process.

The implication of understanding these as separate activities results in, for example, forcing design team members delaying making solution for as long as possible (Bason \& Austin, 2019).

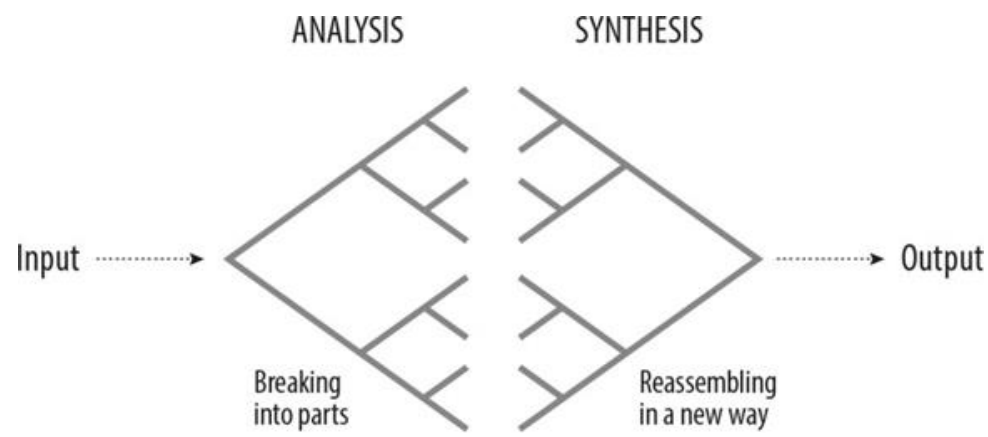

FIGURE 11. Separation of Analysis and Syntheticbased on: Dubberly (2005, p. 22).

\section{DESIGN PROCESS AS A CONTINUOUS IMPROVEMENT}

Popularised within the Total Quality Metagaming (TQM) movement the Continuous Improvement cycle also known as the Shewhart-Deming Plan-Do-Study-Act ${ }^{5}$ Cycle (see Figure 12) was developed for problem solving and it was used in manufacturing to eliminate a waste (1997):

- PLAN (Approach) means to avoid MURI, or [waste caused by] unreasonableness

- DO (Deployment) means to avoid MURA, or to control [waste caused by] inconsistencies

- CHECK (Study/Results) means to avoid MUDA, or to find waste in outcomes ${ }^{6}$

- ACTION (Act/Improvement) indicates the will, motivation, and determination of the Management 


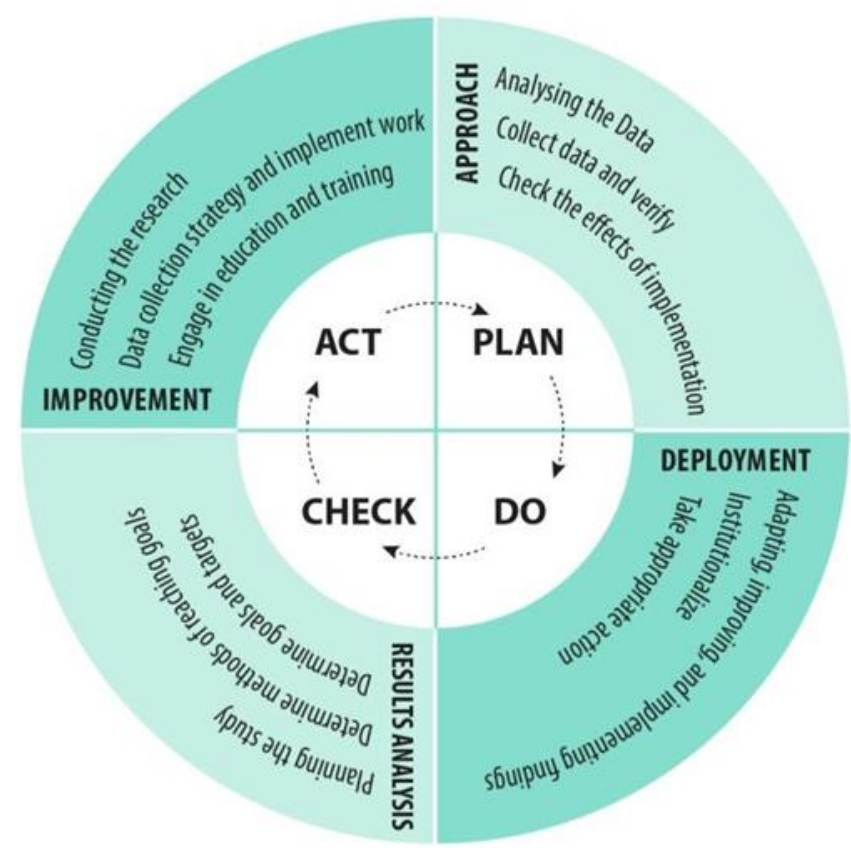

FIGURE 12. The Shewhart-Deming Plan-Do-Study-Act Cycle for problem solving adapted from: G. H. Watson (1993, p. 4), Ishikawa (1985, p. 85), Dubberly (2008, p. 31), (Hamson, 2003, p. 239) and Chestnut (1997, p. 52).

The cycle was adopted as a cyclical design process model to illustrate the 'never ending' cycle of the design improvement. One of the implications of this model is that any development is done in relation to the existingsolution which most likely might prohibit a radical innovation and most likely entrench exiting practices.

\section{DESIGN PROCESS AS A 'MENTAL STATE'}

Some of the most popular models are those of the Institute of Design at Stanford University (d.school). They have been developed to teach design thinking to students from various academic undergraduate and graduateprograms in Stanford, as well as executives and young professionals who take their courses and workshops.

There are many d.school design process models in circulation (see Table 1 and Table 2). However, perhaps the most widespread is the (i) model composed of six stages - understanding, observing, point of view, ideate, prototype and test - represented by coloured circles, from which curved lines display alluding to the iterations. In addition, (ii) the model consisting of five hexagons where empathizing and defining stand out. (iii) A third model includes the same hexagons arranged in a circular shape and adds a final stage of storytelling.

Design Thinking refers to the process that designers 'follow' to address problems and develop proposals with apurpose of solving those problems. As the process includes both cognitive processes and concrete actions, we will refer to those as processes. The differentiators of the d.school models are empathy and prototyping.

These are not only considered as stages, but as a 'mental state' or disposition towards innovation. Empathy seeks to identify motivations, needs and wishes of the people, with the purpose of anticipating behaviours that allow the introduction of innovations that are highly significant and relevant to the users. Prototyping isnot a stage at the end of the creative process, which enables to make adjustments before starting the production, as was conceived in the traditional models (see for example Ulrich \& Eppinger, 2004); on the contrary, it is a way of materialising ideas from a very early stage, with the purpose of communicating and validating them with various stakeholders, as the team members or the users themselves. 
Storytelling is another of the additional elements included in one of the d.school's models. It is different fromthe stages of communication of the traditional models, because it is not geared to describe the proposal for subsequent production, but to build a persuasive story to support the launch of a product or service.

The leaders of IDEO, Kelley and Kelley (2013) and Brown (2009) do not adhere to rigid models, but identify fundamental phases. They proclaim that the processes are not linear and that several iterations are necessarybefore completing the process. Using the acronym HCD (Human-Centred Design), the manual for social innovation developed by IDEO proposes three phases: Hear, Create and Deliver. In synthesis, it is possible to identify the following stages with their characteristics listed in the Table 1. 
TABLE 1. A List of Design Process models adoped from the following sources: Brown (2009), Design Council et al. (2015), d.school, Both, and Baggereor (2013), Kelley and Kelley (2013), IDEO (2009) and Kumar (2012).

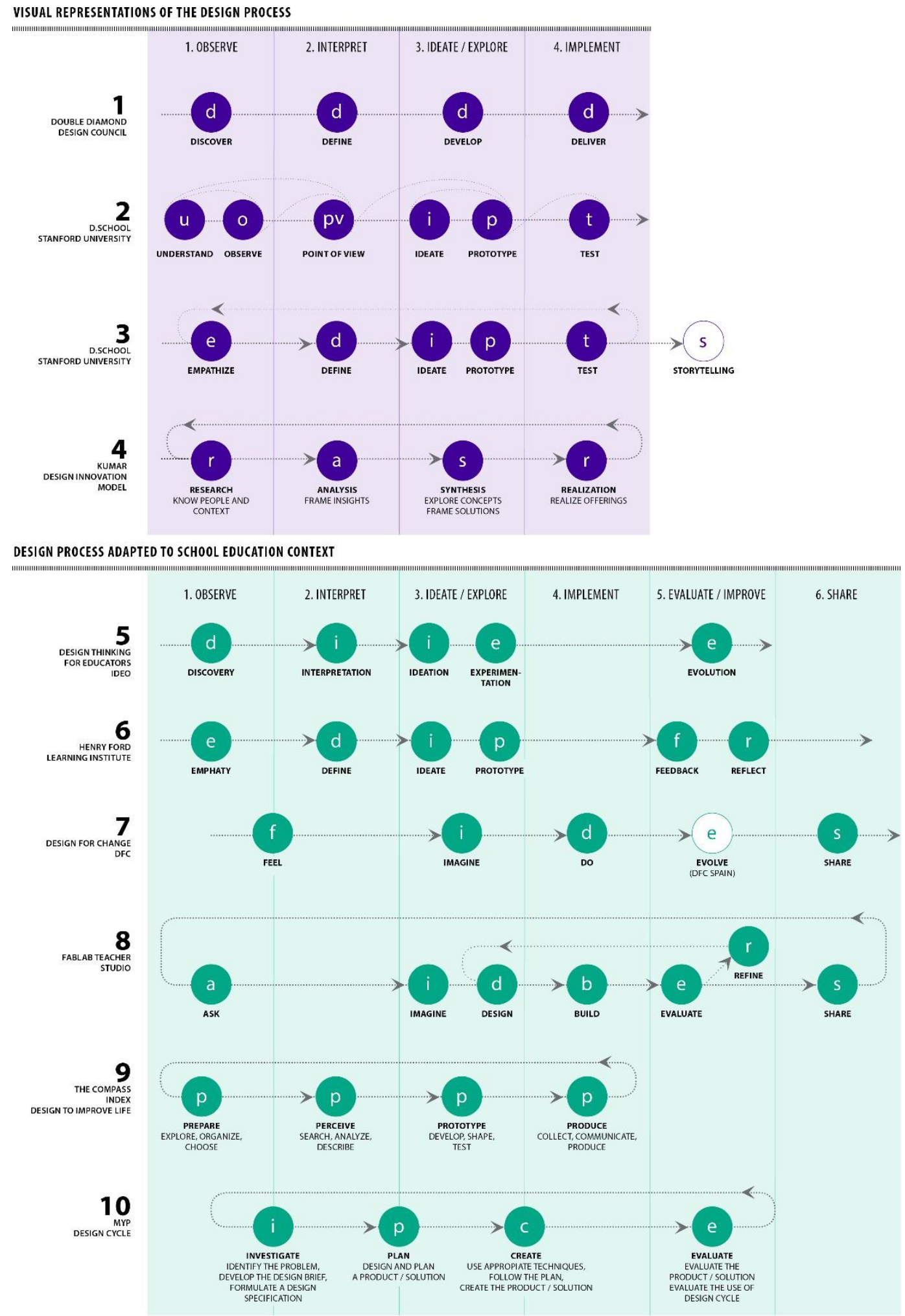




\section{DESIGN PROCESSES AS A LEARNING}

The adaptations of the design process to the educational context also vary in structure, naming and number of stages. In general, the first phases aim is to observe contexts and people, identify and define a problem to develop and explore solutions. However, the testing and implementation stages - that respond to the logic of the productive processes where professional designers operates-are replaced by stages of reflection and evaluation, seeking to promote meta-cognition processes. In some cases, improve and share, are added, enriching the proposals and facilitating their application in other contexts to promote collaborative work between the students. Some models use pictograms that facilitate the identification of each stage. As in the representations of the design process, it is possible to identify linear and cyclical models.

Henry Ford Learning Institute (HFLI) (https://hfli.org/) and Design Thinking for Educators (https://designthinkingforeducators.com) adjusted the models developed by the d.school. HFLI seeks to develop creative thinking and collaborative work, promote empathy, critical thinking and the resolution of problems through learning by doing. The model was developed in conjunction with d.school with the purpose of transferring design thinking to their students. It maintains the stages of empathy, definition, ideation and prototyping, and incorporates feedback and reflection. Each phase is represented using abstract arrows as symbology.

The Design Thinking for Educators manual for teachers-undertaken by IDEO and Riverdale Country School- describes design thinking as a mental ability and is characterized by being collaborative, optimistic, human-centred and oriented towards experimentation. It includes a description of the process, working guides, testimonies and cases in which it has been applied to problems of diverse scale and level of complexity.

Testing is replaced by a stage of evolution, oriented to develop the proposal in time; either looking for the necessary support to carry it out, documenting the process, defining criteria for success, sharing the experience or planning future stages (Riverdale Country School \& IDEO, 2012).

The international Design for Change (DFC) movement (https://www.dfcworld.org/SITE) proposes a methodology of four steps, for children and young people to develop creative proposals to solve problems of their communities. It seeks to develop leadership, empathy, collaboration, and promote analytical thinking and creativity. The stages have pictograms and motivating names as feel, imagine, do and share. DFC Spain (https://www.dfcspain.org/) adds "evolúa" (a term that mixes the words evaluate and evolve). The organization has developed an illustrated manual that invites the children to be superheroes: explains the activities of each stage, proposes questions, promotes reflection and makes suggestions.

FabLab Teacher Studio (DiGiorgio, 2013) proposes a spiral structure of seven steps: question, imagine, design, build, evaluate, refine and share. They have developed a canvas named Project Planning Doc that includes the visual representation of the process, questions that guide the conduction of the different stages, a definition of criteria for assessing results, a list of challenges to improve the proposal and a stage to share results, conclusions and suggestions. It does not include explicitly the observation of users in the initial stage and focuses on manufacture and promotion of collaboration and the transfer of learning. Developed under the influence of the MIT, the model has been used to strengthen critical and creative thinking and the resolution of problems and the integration of content (A. D. Watson, 2015).

The design cycle of the MYP ${ }^{7}$ has a circular structure composed of different stages that are grouped into four main phases: investigate, ideate or plan, create and evaluate. There are numerous versions of this model published online. The shape and structure are maintained, but the names and the number of stages vary. This mode is based on the 'Continuous Improvement' model: Plan, Do, Check and Act (see Figure 13). 
TABLE 2. A list of various design process models.

\begin{tabular}{|c|c|c|c|c|c|}
\hline Reference / Main stages & Observe & Interpret & \multicolumn{2}{|c|}{ Ideate / Explore } & Implement \\
\hline Brown (2009) & Inspiration & \multicolumn{3}{|c|}{ Ideation } & Implementation \\
\hline Design Councilet al. (2005) & Discover & Define & \multicolumn{2}{|c|}{ Develop } & Deliver \\
\hline d.school et al. (2013) & Empathize & Define & Ideate & Prototype & Test \\
\hline d.school by Carroll (2010) & Understand & Point of view & Ideate & Prototype & Test \\
\hline Kelly and Kelly (2013) & Inspiration & Synthesis & \multicolumn{2}{|c|}{ Ideation } & Implementation \\
\hline IDEO, 2009 & Hear & \multicolumn{3}{|c|}{ Create } & Deliver \\
\hline Kumar (2012) & Research & Analysis & \multicolumn{2}{|c|}{ Synthesis } & Realization \\
\hline $\begin{array}{l}\text { Synthesis of the } \\
\text { authors }\end{array}$ & $\begin{array}{l}\text { Know and understand } \\
\text { the context that is going } \\
\text { to be intervened. } \\
\text { It is necessary to } \\
\text { collect data related } \\
\text { to persons (customs, } \\
\text { beliefs, motivations, } \\
\text { etc.) and the context } \\
\text { (economic, productive, } \\
\text { technological, political, } \\
\text { commercial, institutional } \\
\text { aspects, etc.). } \\
\text { The product of this stage } \\
\text { is a set of quantitative } \\
\text { and qualitative data, } \\
\text { images, recordings, } \\
\text { testimonies, etc. } \\
\text { It is a divergent process, } \\
\text { because collected data, } \\
\text { generates the need to } \\
\text { collect more data. }\end{array}$ & $\begin{array}{l}\text { Analyze, relate and } \\
\text { interpret data. } \\
\text { Categorize, classify, and } \\
\text { possibly collect new } \\
\text { information. } \\
\text { The product is a } \\
\text { vision or particular } \\
\text { problematization of the } \\
\text { context and translates } \\
\text { into a hypothesis } \\
\text { or definition of the } \\
\text { problem. } \\
\text { It is an analytical, } \\
\text { abstract and progressive } \\
\text { convergence process. }\end{array}$ & $\begin{array}{l}\text { Generatio } \\
\text { exploratio } \\
\text { Includes d } \\
\text { diagrams, } \\
\text { prototypir } \\
\text { with mate } \\
\text { maps, etc. } \\
\text { Initially is } \\
\text { abstract p } \\
\text { Prototypin } \\
\text { communic } \\
\text { and valida } \\
\text { users. Ma } \\
\text { and move } \\
\text { concrete r }\end{array}$ & $\begin{array}{l}\text { fd } \\
\text { f ideas. } \\
\text { ings, } \\
\text { exploration } \\
\text { s, mental } \\
\text { vergent and } \\
\text { ess. } \\
\text { acilitates } \\
\text { g ideas } \\
\text { them with } \\
\text { lecisions, } \\
\text { vards a } \\
\text { It. }\end{array}$ & $\begin{array}{l}\text { Final testing, } \\
\text { specifications } \\
\text { for production, } \\
\text { implementation and } \\
\text { subsequent evaluation. } \\
\text { It can include the } \\
\text { communication strategy, } \\
\text { to support launching or } \\
\text { deployment. } \\
\text { Can include the final } \\
\text { evaluation and feedback } \\
\text { for the complete process. }\end{array}$ \\
\hline
\end{tabular}

The Compass model by Index, also with a circular structure, proposes four main phases - prepare, perceive, prototype and produce -, each one composed by actions or activities. The system incorporates the three dimensions of sustainability - social, environmental and economic - and sets parameters of evaluation - form, impact and context -. In addition, it defines learning objectives of each phase, describes the activities and proposes techniques to facilitate its implementation. It is a very interesting proposal, which manages to articulate elements from design, education and sustainability.

The enthusiasm generated by Design Thinking in the field of education can be perhaps attributed to their common need to understand people, fundamental for both disciplines: their particularities and motivations; making diagnoses and proposing strategies of intervention and applying creativity, in both diagnosis and troubleshooting. Understanding how designers address these issues are seemed to be valuable for educators, in the light of current methodological requirements and curricula.

\section{CONCLUSION}

Becoming professional entails developing and refining embodied understanding of professional practice that integrates knowing, acting and being in the world (Dall'Alba, 2009). We argue that design process models act as didactic tools by mediating between the aims of instruction (the models) and the outcomes (how to do) (Gellert, 2004). The representations of design process models contribute towards production of the design professional culture. It is through the production, circulations and consumptions of these design process models which contribute to 'shared values' amongst the designers and others who are wishing to adopt this way of working. Images of the design process models, in part, give a meaning to what it means to design (act) and to be a designer (identity).

The representations of the design process vary according to the economic and productive context in which they were developed and the disciplinary and professional influences that generate them. The representationsoriginated in the context of the industrial boom, differ from those developed 
under the influence of emerging technologies and digital economy. The difficulty of graphically representing the design process lies in its problems that 'shift' throughout the process. Feedback processes defy assumed certainties, which require high levels of flexibility. There are cognitive skills, practical procedures, attitudes and productive variables involved, and can be applied to different contexts and address problems of varying complexity.

The design process models do not have any meanings themselves, they signify, it is us who 'read' the meaning. The meaning is constructed by system of representation, which is fixed by the code (Bowker \& Star, 2000). It is the code which makes it possible to establish the 'translation' between those producing representation and those consuming (reading) them. This means that the readers need to have access to both the code and mental maps in order to read the design process models. The design process models are not passive objects. Thus, as with maps representing geographies, the design process models do not fully capture all of the design process 'terrain', they are nevertheless "powerful technologies" (Becker, 1986 cited by Bowker \& Star, 2000, p. 54). The importance of the design process model representations is their 'doing' (agency).

Even though the representations of the process are not formulas or recipes as they are visual analogies that indicate certain milestones that occur during the process and not a path to follow in a strictly linear way, they privilege certain ways of understanding design practices such a separation of doing and thinking.

As design process models are increasingly taken up within the field of education, the understating of their 'doing' as significant didactic resource is becoming imperative. Therefore, we propose a follow-up study to investigate how design process models are used by teachers and by designers, and their interpretation of these in the used context. The reason is to identify how these models are informing what design is as these design process models are one of the vital components which are contributing to the development of Design Literacies. 


\section{REFERENCES}

Akin, Ö. (1986). A Formalism for Problem Restructuring and Resolution in Design. Environment and Planning B: Planning and Design, 13(2), 223-232. https://doi.org/10.1068/b130223

Alexander, C. (1973). Notes on the Synthesis of Form. Harvard University Press. (Original work published 1964)

Allende, N. (2016). Design thinking en las salas de clases [Design thinking trickling into classrooms]. Base Diseño e Innovación, 2, 150-157. https://revistas.udd.cl/index.php/BDI/article/view/229

Banathy, B. H. (1996). Designing Social Systems in a Changing World. Plenum Press. https://doi.org/10.1007/9781-4757-9981-1

Banks, M. (2007). Using visual data in qualitative research. SAGE Publications. https://doi.org/10.4135/9780857020260

Bason, C., \& Austin, R. D. (2019). The Right Way to Lead Design Thinking. Harvard Business Review, (March-April), 82-91. https://hbr.org/2019/03/the-right-way-to-lead-design-thinking

Berger, A. A. (2010). The Objects of Affection: Semiotics and Consumer Culture (Semiotics and Popular Culture). Palgrave Macmillan. https://doi.org/10.1057/9780230109902

Bobbe, T., Krzywinski, J., \& Woelfel, C. (2016). A Comparison of Design Process Models from Academic Theory and Professional Practice. In D. Marjanovic, M. Storga, P. Neven, N. Bojcetic, \& S. Stanko (Eds.), DS 84: Proceedings of the DESIGN 2016: 14th International Design Conference (pp. 1205-1214). Design Society.

Bowker, G. C., \& Star, S. L. (2000). Sorting Things Out: Classification and Its Consequences. MIT Press. https://doi.org/10.7551/mitpress/6352.001.0001

Brown, T. (2009). Change by Design: How Design Thinking Creates New Alternatives for Business and Society: How Design Thinking Can Transform Organizations and Inspire Innovation. HarperCollins.

Buchanan, R. (1992). Wicked Problems in Design Thinking. Design Issues, 8(2), 5-21. https://doi.org/10.2307/1511637

Chestnut, W. R. (1997). Quality Assurance: an Australian Guide to ISO 9000 Certification. Addison Wesley.

Cross, N. (1982). Designerly ways of knowing. Design Studies, 3(4), 221-227. https://doi.org/10.1016/0142$694 \times(82) 90040-0$

Cross, N. (2005 [1999]). Engineering Design Methods Strategies for Product Design (4th ed.). John Wiley \& Sons.

Cross, N. (2011). Design Thinking: Understanding How Designers Think and Work. Berg Publishers. https://doi.org/10.5040/9781474293884

d.school, Both, T., \& Baggereor, D. (2013). Bootcamp Bootleg. https://dschool.stanford.edu/s/METHODCARDS-v3slim.pdf

Dall'Alba, G. (2009). Learning Professional Ways of Being: Ambiguities of becoming. Educational Philosophy and Theory, 41(1), 34-45. https://doi.org/10.1111/j.1469-5812.2008.00475.x

Design Council, Kolarz, P., Simmonds, P. O., Francis, C., Kovacs, H., Sharp, T., \& Wain, M. (2015). Innovation by Design. Design Council.

https://www.designcouncil.org.uk/sites/default/files/asset/document/innovation-by-design.pdf

DFC Global Inc. (2019). Design for Change. https://www.dfcworld.com/

Díaz Barriga Arceo, F., \& Rojas, G. H. (2002). Estrategias docentes para un aprendizaje significativo : una interpretación constructivista [Teaching strategies for meaningful learning: a constructivist interpretation] (2a ed.). McGraw-Hill Interamericana.

DiGiorgio, N. (2013). TEM/FAB Studio: A Teachers' Lounge for Learning and Making. FabLab Teacher Studio. https://sites.google.com/site/stemfabstudio/minicourse/1172011-11112011

Dorst, K. (2011). The core of 'design thinking' and its application. Design Studies, 32(6), 521-532. https://doi.org/10.1016/j.destud.2011.07.006 
Dorst, K., \& Cross, N. (2001). Creativity in the design process: co-evolution of problem-solution. Design Studies, 22(5), 425-437. https://doi.org/10.1016/S0142-694X(01)00009-6

du Gay, P., Hall, S., Janes, L., Mackay, H., \& Negus, K. (1997). Doing Cultural Studies: The Story of the Sony Walkman. SAGE Publications.

Dubberly, H. (2005). How do you design? A Compendium of Models. Dubberly Design Studio http://www.dubberly.com/articles/how-do-you-design.html

Dubberly, H. (2008). Toward a Model of Innovation. Interactions, 18(1), 28-36. https://doi.org/10.1145/1330526.1330538

Dubberly, H., Evenson, S., \& Robinson, R. (2008). On modeling: The analysis-systhesis bridge model. Interactions, 15(2), 57-61. https://doi.org/10.1145/1340961.1340976

Fry, T. (2011). Design as Politics. Berg. https://doi.org/10.5040/9781474293723

Gellert, U. (2004). Didactic material confronted with the concept of mathematical literacy. Educational Studies in Mathematics, 55(1), 163-179. https://doi.org/10.1023/B:EDUC.0000017693.32454.01

Gericke, K., \& Blessing, L. (2012). An analysis of design process models across disciplines. In M. Dorian, S. Mario, P. Neven, \& B. Nenad (Eds.), DS 70: Proceedings of DESIGN 2012: 12th International Design Conference (Vol. Design processes, pp. 171-180). Design Society.

Glen, R., Suciu, C., Baughn, C. C., \& Anson, R. (2015). Teaching design thinking in business schools. The International Journal of Management Education, 13(2), 182-192. https://doi.org/10.1016/j.ijme.2015.05.001

Hall, S. (Ed.) (1997). Representation: Cultural Representations and Signifying Practices. SAGE Publications.

Hamson, N. (2003). Quality, Quality, Management, and Project Management. In E. Verzuh (Ed.), The Portable MBA in Project Management (pp. 207-246). John Wiley \& Sons.

Hassi, L., \& Laakso, M. (2011). Conceptions of Design Thinking in the Design and Management Discourses: Open Questions and Possible Directions for Research. In N. Roozenburg, L.-L. Chen, \& P. J. Stappers (Eds.), IASDR2011, 4th World Conference on Design Research. International Association of Societies of Design Research (IASDR).

Heller, S. (2004). Design literacy: Understanding Graphic Design (2nd ed.). Allworth Press. https://doi.org/10.1093/applin/20.2.237

Holliday, A. (1999). Small Cultures. Applied Linguistics, 20(20), 237-264. https://doi.org/10.1093/applin/20.2.237

Howard, T. J., Culley, S. J., \& Dekoninck, E. (2008). Describing the creative design process by the integration of engineering design and cognitive psychology literature. Design Studies, 29(2), 160-180. https://doi.org/10.1016/j.destud.2008.01.001

IDEO. (2009). Design Kit: The Human-Centered Design Toolkit. http://www.ideo.com/images/uploads/hcd_toolkit/IDEO_HCD_ToolKit.pdf

INDEX: Design to Improve Life. (2019). Compass. https://designtoimprovelifeeducation.dk/design-to-improve-life/

Ingram, J., Shove, E., \& Watson, M. (2007). Products and Practices: Selected Concepts from Science and Technology Studies and from Social Theories of Consumption and Practice. Design Issues, 23(2), 3-16. https://doi.org/10.1162/desi.2007.23.2.3

Ishikawa, K. (1985). What Is Total Quality Control? - The Japanese Way (D. J. Lu, Trans.). Prentice-Hall.

Jermier, J. M., \& Forbes, L. C. (2011). Metaphor as the Foundation of Organizational Studies: Images of Organization and Beyond. Organization \& Environment, 24(4), 444-458. https://doi.org/10.1177/1086026611436328

Johansson-Sköldberg, U., Woodilla, J., \& Çetinkaya, M. (2013). Design Thinking: Past, Present and Possible Futures. Creativity and Innovation Management, 22(2), 121-146. https://doi.org/10.1111/caim.12023

Kelley, T., \& Kelley, D. (2013). Creative confidence: unleashing the creative potential within us all. Crown Business. 
Kitano, \& Toyota Motor Manufacturing. (1997, 14-16 May). Toyota Production System: "one-by-one confirmation". Paper presented at the Lean Manufacturing Conference, University of Kentucky.

Koberg, D., \& Bagnall, J. (1981). The All New Universal Traveler: A Soft-Systems Guide to Creativity, ProblemSolving, and the Process of Reaching Goals. William KaufmannLos. (Original work published 1972)

Kolko, J. (2018). We are illiterate: We have no design literacy. The Modernist Studio. http://www.themoderniststudio.com/2018/08/20/we-are-illiterate/

Kress, G., \& van Leeuwen, T. (2006). Reading Images (2nd ed.). Routledge. https://doi.org/10.4324/9780203619728

Kumar, V. (2012). 101 Design Methods: A Structured Approach for Driving Innovation in Your Organization. John Wiley \& Sons.

Lawson, B. (2004). What Designers Know. Architectural Press.

Lawson, B. (2005). How Designers Think: The Design Process Demystified (4th ed.). Architectural Press. https://doi.org/10.4324/9780080454979

Liedtka, J., \& Ogilvie, T. (2011). Designing for Growth: A Design Thinking Toolkit for Managers. Columbia Business School Publishing.

Maher, M. L., Poon, J., \& Boulanger, S. (1996). Formalising Design Exploration as Co-Evolution. In J. S. Gero \& F. Sudweeks (Eds.), Advances in Formal Design Methods for CAD: Proceedings of the IFIP WG5.2 Workshop on Formal Design Methods for Computer-Aided Design, June 1995 (pp. 3-30). Springer US. https://doi.org/10.1007/978-0-387-34925-1_1

Martin, R. L. (2009). The design of business: why design thinking is the next competitive advantage. Harvard Business Press.

McComb, C., Cagan, J., \& Kotovsky, K. (2014). Quantitative Comparison of High- and Low-Performing Teams in a Design Task Subject to Drastic Changes. In ASME 2014 International Design Engineering Technical Conferences and Computers and Information in Engineering Conference (Vol. 7: 2nd Biennial International Conference on Dynamics for Design; 26th International Conference on Design Theory and Methodology). https://doi.org/10.1115/detc2014-34653

McComb, C., Cagan, J., \& Kotovsky, K. (2015). Rolling with the punches: An examination of team performance in a design task subject to drastic changes. Design Studies, 36, 99-121. https://doi.org/10.1016/j.destud.2014.10.001

Meirelles, I. (2013). Design for information: an introduction to the histories, theories, and best practices behind effective information visualizations. Rockport Publishers.

Mijksenaar, U. (1974). Signposting and Communication Media. Icographic 7, 15-21.

Mol, A. (2008). The logic of care: Health and the Problem of Patient Choice. Routledge.

Morgan, G. (1997]). Images of Organization (2nd ed.). SAGE Publications. (Original work published 1986) https://doi.org/10.4324/9780203927076

Munari, B. (1989). Cómo Nacen los Objetos: Apuntes para una metodología proyectual [How Objects Are Born: Notes for a project methodology](G. Gili, Trans. 3a ed.). Publicado por Gius. (Original work published 1981)

Nielsen, L. M. (2013). Design Learning for Tomorrow - Design Education from Kindergarten to PhD. In J. B. Reitan, P. Lloyd, E. Bohemia, L. M. Nielsen, I. Digranes, \& E. Lutnæs (Eds.), Design Education from Kindergarten to PhD - Design Learning for Tomorrow: Proceedings of the 2nd International Conference for Design Education Researchers (pp. i-iii). ABM-media.

Norman, D. A., \& Verganti, R. (2013). Incremental and Radical Innovation: Design Research vs. Technology and Meaning Change. Design Issues, 30(1), 78-96. https://doi.org/10.1162/DESI_a_00250

Ohno, T. (1988). Toyota Production System: Beyond Large-Scale Production. Routledge. (Original work published 1978) 
Pacione, C. (2010). Evolution of the Mind: A Case for Design Literacy. Interactions, 17(2), 6-11. https://doi.org/10.1145/1699775.1699777

Pacione, C. (2017). Let's Do Right by Design by Helping Everyone Else Do Design Right. Design Management Review, 28(4), 29-31. https://doi.org/10.1111/drev.12098

Razzouk, R., \& Shute, V. (2012). What Is Design Thinking and Why Is It Important? Review of Educational Research, 82(3), 330-348. https://doi.org/10.3102/0034654312457429

Rittel, H. W. J., \& Webber, M. M. (1973). Dilema in a General Theory of Planning. Policy Science, 4, 155-169. https://doi.org/10.1007/BF01405730

Riverdale Country School, \& IDEO. (2012). Design Thinking for Educators Toolkit. http://www.designthinkingforeducators.com/DTtoolkit_v1_062711.pdf

Simon, H. A. (1988). The Science of Design: Creating the Artificial. Design Issues, 4(1/2), 67-82. https://doi.org/10.2307/1511391

Stenlev, L., \& Boegeskov, L. (2016). Index: Aprendizaje innovador desde el colegio: La experiencia danesa [Innovative learning from school: the Danish experiencie]. Base Diseño e Innovación, 3(2), 50-61.

Stigliani, I. (2017, 22 June). Design thinking - the skill every MBA student needs. Financial Times. https://www.ft.com/content/cbf70424-422a-11e7-82b6-896b95f30f58

Tversky, B. (2001). Structures of Mental Spaces. In M. Gattis (Ed.), Spatial Schemas and Abstract Thought. MIT Press.

Ulrich, K. T., \& Eppinger, S. D. (2000). Product Design and Development (2nd ed.). McGraw-Hill Higher Education.

Ulrich, K. T., \& Eppinger, S. D. (2004). Product Design and Development (3rd ed.). McGraw- Hill/Irwin.

Watson, A. D. (2015). Design Thinking for Life. Art Education, 68(3), 12-18. https://doi.org/10.1080/00043125.2015.11519317

Watson, G. H. (1993). Strategic Benchmarking: How to rate your company's performance against the world's best. John Wiley \& Sons.

Wilkes, P. V. (1989). Images of Organization: An Essay Review. Journal of Educational Administration, 27(2), 6771. https://doi.org/10.1108/eb009961

Wölfel , C., Debitz, U., Krzywinski, J., \& Stelzer, R. (2012). Methods Use in Early Stages of Engineering and Industrial Design - A Comparative Field Exploration. In D. Marjanović, M. Štorga, N. Pavković, \& N. Bojčetić (Eds.), DS 70: Proceedings of DESIGN 2012, the 12th International Design Conference (Vol. 3, pp. 1397-1404). Design Society.

Wynn, D., \& Clarkson, J. (2005). Models of Design. In J. Clarkson \& C. Eckert (Eds.), Design process improvement (pp. 34-59). Springer Verlag. https://doi.org/10.1007/978-1-84628-061-0_2

\footnotetext{
${ }^{1}$ First published as Bravo, Ú. \& Bohemia, E. (2019). Roles of Design Processes Models as Didactic Materials. Conference Proceedings of the Academy for Design Innovation Management, 2(1). The article is republished with permission.

2 This separation between production and consumptions is not as clear cut. The reason is that designers and design educators who 'inscribe' design practices into design processes for benefits of their colleagues, clients and students may be using these models themselves.

${ }^{3}$ For the purposes of this article, thought and process are used indistinctly to refer to the set of activities, stages, abilities, skills and attitudes deployed by designers in the development of their projects. It is not the objective to focus on analysing the meanings and emphasis associated with each term, although it may be an interesting challenge to address in the future.

${ }^{4}$ Mnemonic is a device such as a pattern of letters, ideas, or associations that assists in remembering something.

${ }^{5}$ There are many variations on how these steps are named.

${ }^{6}$ Explanations of muri, mura and muda see Kitano and Toyota Motor Manufacturing (1997) and Ohno (1988).

${ }^{7} \mathrm{MYP}$ It is the English acronym for Middle Years Program, corresponding to the intermediate cycle-from 11 to 16 years - of the IB or International Baccalaureate.
} 